\title{
₹USES
}

science for a changing world

Prepared in cooperation with the New York City Department of Environmental Protection

\section{Estimates of Natural Streamflow at Two Streamgages on the Esopus Creek, New York, Water Years 1932 to 2012}

Scientific Investigations Report 2015-5050 
Cover. The West Basin of Ashokan Reservoir at sunset. Photograph by Elizabeth Nystrom, 2013. 


\section{Estimates of Natural Streamflow at Two Streamgages on the Esopus Creek, New York, Water Years 1932 to 2012}

By Douglas A. Burns and Christopher L. Gazoorian

Prepared in cooperation with the

New York City Department of Environmental Protection

Scientific Investigations Report 2015-5050 


\title{
U.S. Department of the Interior SALLY JEWELL, Secretary
}

\section{U.S. Geological Survey \\ Suzette M. Kimball, Acting Director}

\author{
U.S. Geological Survey, Reston, Virginia: 2015
}

For more information on the USGS - the Federal source for science about the Earth, its natural and living resources, natural hazards, and the environment—visit http://www.usgs.gov or call 1-888-ASK-USGS.

For an overview of USGS information products, including maps, imagery, and publications, visit http://www.usgs.gov/pubprod/.

Any use of trade, firm, or product names is for descriptive purposes only and does not imply endorsement by the U.S. Government.

Although this information product, for the most part, is in the public domain, it also may contain copyrighted materials as noted in the text. Permission to reproduce copyrighted items must be secured from the copyright owner.

Suggested citation:

Burns, D.A., and Gazoorian, C.L., 2015, Estimates of natural streamflow at two streamgages on the Esopus Creek, New York, water years 1932-2012: U.S. Geological Survey Scientific Investigations Report 2015-5050, 20 p., http://dx.doi.org/10.3133/sir20155050.

ISSN 2328-0328 (online) 


\section{Contents}

Abstract
Introduction
Study Site
Methods Scope
Study Approach
Sources of Discharge Data
Analyses of Discharge Data
Estimated Natural Discharge Results
Regression Models for Estimating Natural Discharge at the Coldbrook Streamgage
$\quad$ Comparison of Estimated Natural Discharge and Gaged Discharge at the Coldbrook
$\quad$ Mount Marion Streamgage
$\quad$ Streamgages with Annual Runoff at Nearby Catskill Streamgages
$\quad$ With Alluvial Groundwater

\section{Figures}

1. Maps showing Esopus Creek and West of Hudson/Catskill and Delaware System watersheds, New York

2. Graphs showing daily-discharge values predicted by two multiple regression models applied to estimate natural daily discharge at the Esopus Creek at Coldbrook streamgage (01362500) from October 1, 1931, to September 30, 2012.

3. Graph showing flow-duration curves based on gaged daily discharge and natural daily-discharge estimates for the Coldbrook streamgage (01362500) from 0ctober 1 , 1931, to September 30, 2012.

4. Graph showing flow-duration curves based on gaged daily discharge and natural daily-discharge estimates for the Mount Marion streamgage (01364500) from October 1, 1970, to September 30, 2012

5. Graph showing flow-duration curves based on natural daily-discharge estimates for the Mount Marion streamgage (01364500) from October 1, 1931, to September 30, 2012, and from October 1, 1970, to September 30, 2012.

6. Graphs showing discharge measures from streamgages on the Esopus Creek and the Shandaken Tunnel, New York 


\section{Tables}

1. Basin characteristics of the Esopus Creek watershed at the Coldbrook, New York, streamgage (01362500), at the Mount Marion, N.Y., streamgage (01364500), and at the point of discharge to the Hudson River.

2. Basin characteristics of seven streamgages that were used either as predictive variables in the estimation of natural discharge in the Esopus Creek at the Coldbrook, New York, streamgage or in calculations of annual runoff for comparison with gaged and natural runoff in the Esopus Creek at Coldbrook and Mount Marion, N.Y., streamgages .

3. Description of flow metrics calculated by the Indicators of Hydrologic Alteration software for each discharge record analyzed in this study

4. Range of gaged daily discharge and natural daily-discharge estimates as well as mean relative difference between these values as a function of flow exceedance range for the Coldbrook, New York, streamgage (01362500) from October 1, 1931, to September 30, 2012.

5. Gaged daily discharge and estimated natural daily discharge as well as the difference and relative differences between these values as a function of mean annual flow metrics for consecutive-day low-flow and high-flow days for the Coldbrook, New York, streamgage (01362500) from October 1, 1931, to September 30,2012

6. Range of gaged daily discharge and natural daily-discharge estimates as well as mean relative difference of these values as a function of flow exceedance values for the Mount Marion, New York, streamgage (01364500) from October 1, 1970, to September 30, 2012.

7. Gaged daily discharge and estimated natural daily discharge as well as the difference and relative difference of these values as a function of mean annual flow metrics for consecutive-day low-flow and high-flow days for the Mount Marion streamgage (01364500) from October 1, 1970, to September 30, 2012

8. Mean annual runoff based on gaged and estimated natural daily discharge at the Coldbrook, New York (01362500), and Mount Marion, N.Y. (01364500), streamgage sites along with mean annual runoff for three other gaged sites in the Catskill Mountain region from October 1, 1931, to September 30, 2012, and seven other gaged sites from 0 ctober 1, 1970, to September 30, 2012. Annual runoff values are expressed in inches 


\section{Conversion Factors}

Inch/Pound to International System of Units

\begin{tabular}{lcl}
\hline & Bultiply & \multicolumn{1}{c}{ To obtain } \\
\hline inch (in.) & Length & \\
foot (ft) & 2.54 & centimeter $(\mathrm{cm})$ \\
mile (mi) & 0.3048 & meter $(\mathrm{m})$ \\
& 1.609 & kilometer $(\mathrm{km})$ \\
\hline square mile $\left(\mathrm{mi}^{2}\right)$ & Area & \\
square mile $\left(\mathrm{mi}^{2}\right)$ & 259.0 & hectare $(\mathrm{ha})$ \\
\hline & 2.590 & square kilometer $\left(\mathrm{km}^{2}\right)$ \\
\hline cubic foot per second $\left(\mathrm{ft}{ }^{3} / \mathrm{s}\right)$ & Flow rate & \\
million gallons per day $(\mathrm{Mgal} / \mathrm{d})$ & 0.02832 & cubic meter per second $\left(\mathrm{m}^{3} / \mathrm{s}\right)$ \\
\hline
\end{tabular}

\section{Datum}

Vertical coordinate information is referenced to North American Vertical Datum of 1988 (NAVD 88).

Horizontal coordinate information is referenced to North American Datum of 1983 (NAD 83).

Elevation, as used in this report, refers to distance above the vertical datum.

\section{Abbreviations}

IHA Indicators of Hydrologic Alteration software

NYSET New York Streamflow Estimation Tool

USGS U.S. Geological Survey

WY water year 



\title{
Estimates of Natural Streamflow at Two Streamgages on the Esopus Creek, New York, Water Years 1932 to 2012
}

\author{
By Douglas A. Burns and Christopher L. Gazoorian
}

\section{Abstract}

Streamflow in the Esopus Creek watershed is altered by two major watershed management activities carried out by the New York City Department of Environmental Protection as part of its responsibility to maintain a water supply for New York City: (1) diversion of water from the Schoharie Creek watershed to the Esopus Creek through the Shandaken Tunnel, and (2) impoundment of the Esopus Creek by a dam that forms the Ashokan Reservoir and subsequent release through the Catskill Aqueduct. Stakeholders in the Catskill region are interested and concerned about the extent to which these watershed management activities have altered streamflow, especially low and high flows, in the Esopus Creek. To address these concerns, natural (in the absence of diversion and impoundment) daily discharge from October 1, 1931, to September 30, 2012, was estimated for the U.S. Geological Survey streamgages at Coldbrook (station number 01362500), downstream of the Shandaken Tunnel discharge, and at Mount Marion (01364500), downstream of the Ashokan Reservoir.

A multiple linear regression approach, using nearby discharge records from unimpounded streams as predictive variables, was applied to estimate natural discharge at the Coldbrook streamgage. Estimated values of natural daily discharge at the Coldbrook streamgage were lower than values of gaged daily discharge throughout the flow range at this site. At moderate- and low-flow conditions, gaged daily-discharge values were about two to three times greater than natural daily-discharge estimates, whereas the difference between the two records was less than 5 percent for the highest 1 percent of daily-discharge values. These results indicate that Shandaken Tunnel discharge has a minor effect on flooding in the Esopus Creek Basin. However, a difference of 5 percent is within the uncertainty of the regression-based natural discharge estimates for Coldbrook; thus, it cannot be stated with certainty that the Tunnel has on average any effect on flow for the highest 1 percent of daily discharge values.

Natural discharge at the Mount Marion streamgage was estimated by summing the natural discharge estimated for the Coldbrook streamgage and the discharge estimated for the intervening basin area through application of the New York Streamflow Estimation Tool, recently developed for estimating unaltered streamflow at ungaged locations in the State.
Estimates of natural daily discharge at the Mount Marion streamgage were about three times greater than gaged daily discharge throughout the moderate- to low-flow range from October 1, 1970, to September 30, 2012, the period of record for full water years at this streamgage. The relative difference between the two discharge time series declined as flow increased beyond the moderate range, but gaged daily discharge was still 25 to 43 percent less than estimated natural daily discharge for the high-flow metrics calculated in this analysis, and the mean relative difference was 43 percent for the annual 1-day maximum discharge. Overall, these estimates of natural discharge reflect the absence of effects of the Shandaken Tunnel and Ashokan Reservoir on flows in the Esopus Creek over broad time frames. However, caution is warranted if one is attempting to apply the natural estimates at short time scales because the regression prediction intervals indicate that uncertainty at a daily time step ranges from about 40 to 80 percent.

\section{Introduction}

The natural flow regimes of Earth's streams and rivers are greatly altered by human activities such as withdrawals for water supply and irrigation, discharges from point sources, and impoundment (Vörösmarty and Sahagian, 2000; Eng and others, 2013). As examples of the extent of this alteration, about 20 percent of global continental runoff is stored behind registered dams (Vörösmarty and Sahagian, 2000), and more than half of global runoff accessible to humans is withdrawn or maintained for instream uses (Postel and others, 1996). Human exploitation of rivers has wide ranging implications, including changes in the following: the flow and thermal regimes of rivers, aquatic and riparian ecological communities, the geomorphology of channel networks and flood plains, water quality, and land-use patterns (Rosenberg and others, 2000; Magilligan and Nislow, 2005). Temporal patterns in population growth and per capita water use indicate that human alteration of the global water cycle and river flow regimes is increasing and suggest that further increases are likely in the future (Wada and others, 2013). Although many of the effects of human water use have deleterious environmental consequences, the benefits of water use are numerous and include food 
production, electricity generation, recreation, flood reduction, and improved health outcomes (Gleick, 1996). This complex mix of benefits and adverse effects often creates water management conflicts among interest groups with divergent priorities. Successful resolution of water-use conflicts presents a challenge and forms the basis of good water management (Wolf and others, 2005).

The Catskill Mountain region of southeastern New York is valued for its water resources, and its water has long been used for human activities such as recreation, industry, and water supply (Francis, 1988; Swaney and others, 2006). Streamflow and water quality in the region have been altered by human activities that date to at least the 19th century, when leather tanneries diverted flow and severely polluted waterways (Swaney and others, 2006). New York City began to play a large role in the use and management of water resources in the Catskills in the early 20th century. The city's water-supply needs were forecast to exceed the available Croton water supply, and the newly established Bureau of Water Supply then began to acquire land in the Catskills to build dams, reservoirs, and aqueducts for what would become the City's West of Hudson water supply (Iwan, 1987).

The first reservoir completed, the Ashokan, began delivering water to the city through the Catskill Aqueduct in 1915 (Galusha, 1999). Development of the West of Hudson water supply continued through the mid-1960s until the sixth reservoir, the Cannonsville, was completed and began to deliver water downstate through the Delaware Aqueduct. The extensive use of water from the Catskills by New York City has often pitted the interests of the city in protecting its water supply against those of governmental agencies at the municipal, county, and state levels, as well as those of regional citizen and interest groups (Soll, 2013). These conflicts have played out against a backdrop of regulatory enforcement that has driven watershed and water-supply management requirements that New York City must meet under laws such as the Safe Drinking Water Act (42 U.S.C. \$300f et seq.) and Clean Water Act (33 U.S.C. \$1251 et seq.; McClure, 2007; Smith and Porter, 2010).

The six reservoirs in the Catskills that form the New York West of Hudson water-supply system, along with smaller reservoirs and impoundments, have altered the natural flow regime in the region. Although the City's reservoirs were not designed for flood control, impoundment has diminished and attenuated flood peaks and decreased base flow (Zembrzuski and Evans, 1989; Suro and Firda, 2006; Milone and MacBroom, Inc., 2009). The New York City Department of Environmental Protection manages the City's water-supply system in accordance with several regulations that dictate releases from the reservoirs. This mix of mandatory and voluntary regulations is carried out under the guidance of the New York State Department of Environmental Conservation (2014a), the U.S. Environmental Protection Agency (2014), and the Delaware River Basin Commission (http://www.state.nj.us/drbc/). Some of these regulations are designed to minimize downstream flood effects by increasing releases in advance of periods when flood risk is high and when refilling of reservoirs in the near future is likely.

The Esopus Creek is an example of a watershed in which diversions for New York City's water supply have altered the natural flow regime. Water is transferred from the Schoharie Reservoir to the Esopus Creek through the 18-mile (mi) Shandaken Tunnel. This diversion increases the flow of the Esopus Creek, and businesses that offer float trips on inner tubes and other watercraft are dependent on this enhanced discharge during summer low-flow periods. Regulations govern releases from the tunnel to serve these recreational needs (New York State Department of Environmental Conservation, 2014b). Because the Shandaken Tunnel provides up to 600 million gallons per day (Mgal/d; about 930 cubic feet per second [ $\left.\mathrm{ft}^{3} / \mathrm{s}\right]$ ) to the Esopus Creek, the issue of whether the tunnel increases the magnitude of floods in the Creek has long been controversial. Reports as far back as the mid-20th century blame Shandaken Tunnel discharges for increased flood damage (Van Burkalow, 1959).

Downstream of the U.S. Geological Survey (USGS) streamgage at Coldbrook (station number 01362500), the Esopus Creek is impounded by a dam that forms the Ashokan Reservoir. About 350 to $400 \mathrm{Mgal} / \mathrm{d}$ of water is diverted downstate from this reservoir through the Catskill Aqueduct to serve New York City's water-supply needs. A spillway discharges back into the Esopus Creek (upstream of the USGS streamgage at Mount Marion [01364500]) when the Reservoir is full or when gated releases are occurring to serve objectives such as minimizing downstream floods. Lowered base flow and decreased high flow in the Esopus Creek downstream of the dam have been noted previously (Suro and Firda, 2007; Milone and MacBroom, Inc., 2009). In addition to the Ashokan Reservoir, there are three other impoundments in the Esopus Creek Basin, the largest of which is Cooper Lake, a water supply for the city of Kingston (http://www.kingston-ny.gov/ content/76/78/1005/default.aspx). However, this lake is quite small, with a storage volume equivalent to about 1 percent of the Ashokan Reservoir volume.

The Esopus Creek is also an example of a Catskill watershed about which the water management interests of New York City have often conflicted with the interests of various stakeholders, such as governmental organizations and citizen groups (Postel and Thompson, 2005; Kane and Erickson, 2007). A variety of issues have arisen about the management of flow and water quality in the Esopus Creek that include protecting fish habitat, supporting water recreation businesses, minimizing flooding and flood damage, and managing excessive turbidity. Turbidity in the Esopus Creek Basin has been a prominent issue, and a successful lawsuit in which the Shandaken Tunnel was determined to be a point source of sediment pollution under the Clean Water Act (McClure, 2007) has resulted in considerable effort by the New York City Department of Environmental Protection to minimize tunnel diversions during periods of high turbidity.

The focus of the current study by the U.S. Geological Survey, in cooperation with the New York City Department 
of Environmental Protection, is to determine the natural flow conditions in the Esopus Creek at two key locations, represented by USGS streamgages at (1) Coldbrook, N.Y. (01362500), and (2) Mount Marion, N.Y. (01364500). The Coldbrook streamgage is $10.5 \mathrm{mi}$ downstream of the Shandaken Tunnel and therefore receives additional discharge on days when flow is exiting the tunnel. The Mount Marion streamgage is $31.6 \mathrm{mi}$ downstream of the Ashokan Reservoir and therefore receives less discharge than would naturally be received from upstream sources.

\section{Purpose and Scope}

This report describes the development and application of a method that provides estimates of natural discharge in the Esopus Creek at two streamgages (Coldbrook and Mount Marion) for water years (WYs) 1932 through 2012 (a water year begins on October 1 of the preceding calendar year and ends on September 30). Flow at these streamgages is affected by the water management activities of the New York City Department of Environmental Protection. The purpose of this report is to provide broad multiyear comparisons of the natural dailydischarge estimates with the gaged daily-discharge record across a range of flow conditions at these sites to describe the extent to which the Shandaken Tunnel and Ashokan Reservoir affect streamflow in the Esopus Creek Basin. The report evaluates the validity of the estimates of natural daily discharge by (1) comparing estimated natural discharge at the Coldbrook streamgage with gaged discharge for days when water management effects were negligible and (2) comparing natural runoff at these two streamgages with natural runoff from six streamgages in the region that are not affected by diversion or impoundment.

"Natural" in this instance indicates Esopus Creek flow that is affected neither by discharge from the Shandaken Tunnel nor by impoundment in the Ashokan Reservoir and subsequent diversion of flow to New York City through the Catskill Aqueduct. The term "gaged discharge" at these two streamgages refers to values that are influenced by discharge from the Shandaken Tunnel and by impoundment and consequent diversion downstate from the Ashokan Reservoir. Other human development, including roads, residences, and towns in the Esopus Creek Basin, likely has some effect on streamflow. Furthermore, the effect of human development on streamflow in the basin likely increased over the study period. This report assumes that the effect of human development in the Esopus Creek Basin, which is minor compared with the heavy development of urbanized watersheds, is likely affecting streamflow much less than that of New York City's water-supply management activities. Specifically, the report is predicated on the assumption that the Shandaken Tunnel and the Ashokan Reservoir and Catskill Aqueduct are the two major human influences on streamflow in the Esopus Creek Basin. There are other small impoundments in the Esopus Creek Basin, but the scale of these structures is much smaller than that of the Ashokan Reservoir. The results of this study should provide an improved understanding of the effects of flow management on low flows and floods in this basin.

\section{Study Site}

The Esopus Creek, a tributary of the Hudson River with headwaters in the Catskill Mountains, drains a watershed area of 424 square miles $\left(\mathrm{mi}^{2}\right)$ at the point of discharge to the river (fig. 1). The Esopus Creek at the Mount Marion streamgage, downstream of the Ashokan Reservoir, drains a watershed area of $419 \mathrm{mi}^{2}$, and the Esopus Creek at Coldbrook streamgage, upstream of the Reservoir but downstream of the Shandaken Tunnel discharge, drains a smaller watershed area of 192 $\mathrm{mi}^{2}$ (fig. 1). A watershed area of $256 \mathrm{mi}^{2}$ is regulated by the Ashokan Reservoir, and when the influence of the reservoir is combined with that of three additional impoundments in the Esopus watershed, the effective drainage area of the Mount Marion streamgage is $112 \mathrm{mi}^{2}$, about 27 percent of the true drainage area. However, a spillway and gates release excess water from the reservoir that re-enters the Esopus Creek downstream of the dam but upstream of the Mount Marion streamgage. These releases occur primarily during high flow, but water can be released for other purposes. During WYs 1971 through 2012, the daily mean discharge in the spillway channel was $158.3 \mathrm{ft}^{3} / \mathrm{s}$, but there was no flow release on 80.1 percent of the days (J. Porter, New York City Department of Environmental Protection, written commun., 2014). For the 19.9 percent of days when discharge was noted, the effective drainage area of the reservoir is uncertain.

The headwaters of the Esopus Creek watershed originate on Slide Mountain, which has the highest elevation in the Catskills. These headwaters receive mean annual precipitation of 63.6 inches (in.; Northeast Regional Climate Center, 2014), a value among the highest in New York and all of the northeastern United States. The Esopus Creek watershed drains steeply from the westernmost headwaters to the USGS streamgage at Allaben, N.Y. (01362200), a basin of $63.7 \mathrm{mi}^{2}$. At the Coldbrook streamgage, downstream of the Shandaken Tunnel, the watershed remains steep, with a mean slope of 31.0 percent (table 1$)$, and is mainly forested ( 97.8 percent of basin), with only minor influence from urban land use (0.61 percent of basin). Downstream of the reservoir at the Mount Marion streamgage, the basin is, on average, less steep than at the Coldbrook streamgage, with less forest cover and more urban land, but mean annual precipitation remains quite high for New York at 48.1 in. (table 1).

\section{Methods}

The approach described in the project proposal was changed after an initial exploration of the data showed that 


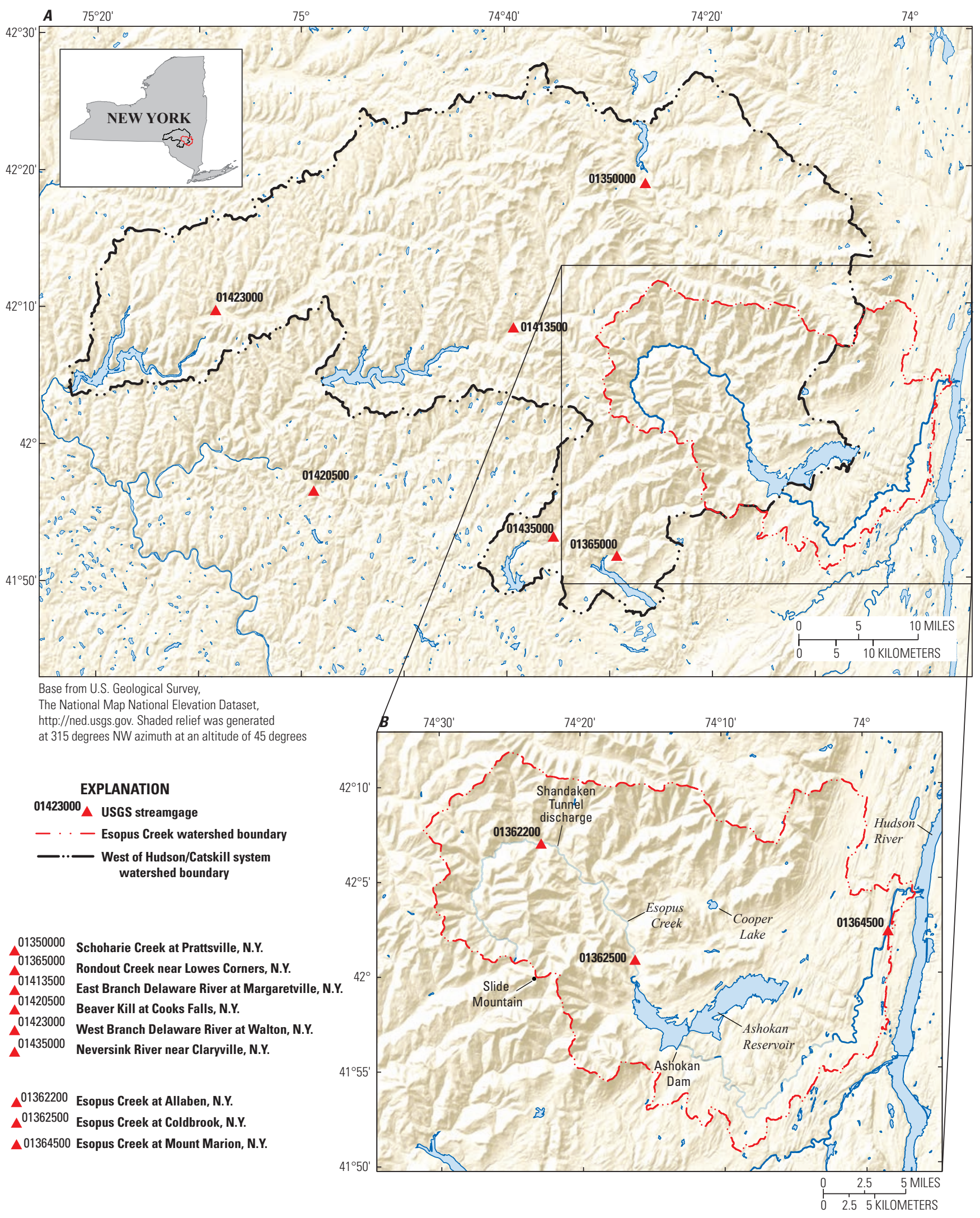

Figure 1. Esopus Creek and West of Hudson/Catskill and Delaware System watersheds, New York. A, watershed boundaries and six U.S. Geological Survey (USGS) streamgages located outside of the Esopus Creek and used in this study. B, Esopus Creek watershed with USGS streamgages at Allaben, Coldbrook, and Mount Marion; Slide Mountain, the outflow of the Shandaken Tunnel, the Ashokan Reservoir with dam, Cooper Lake, and the Hudson River are also shown. N.Y., New York. 
Table 1. Basin characteristics of the Esopus Creek watershed at the Coldbrook, New York, streamgage (01362500), at the Mount Marion, N.Y., streamgage (01364500), and at the point of discharge to the Hudson River.

[Data are from U.S. Geological Survey (2014a). N.Y., New York; Mt., Mount; mean annual values are for the period 1951-1980]

\begin{tabular}{lccc}
\hline \multicolumn{1}{c}{ Basin characteristics } & \multicolumn{3}{c}{ Streamgage } \\
\hline & Esopus Creek at Coldbrook, N.Y. & Esopus Creek at Mt. Marion, N.Y. & Esopus Creek at Hudson River \\
Drainage area, in square miles & 192 & 419 & 424 \\
Mean basin slope, in percent & 31.0 & 22.3 & 22.2 \\
Basin storage ${ }^{1}$, in percent & 0.26 & 3.42 & 3.45 \\
Forested area, in percent & 97.8 & 88.7 & 88.3 \\
Urban area, in percent & 0.61 & 2.85 & 3.03 \\
Mean annual runoff, in inches & 31.6 & 28.6 & 28.4 \\
Mean annual precipitation, in inches & 50.9 & 48.1 & 47.9 \\
\hline
\end{tabular}

${ }^{1}$ Percentage of total area in lakes, ponds, and wetlands.

the assumptions of the proposed methodology were not met. This originally proposed approach was to subtract the Shandaken Tunnel discharge from that of the Coldbrook streamgage to estimate natural discharge at Coldbrook. This proposed approach failed to provide discharge estimates that could confidently be assumed to represent natural flow conditions. The results of this originally proposed approach are briefly described in a later section of this report. The alternative approach that was applied to obtain natural streamflow estimates is described in this section.

\section{Study Approach}

Natural discharge at the Coldbrook streamgage was estimated through a multiple linear regression approach for days when the Shandaken Tunnel had little effect on discharge in the Esopus Creek, which were assumed to be days when Shandaken Tunnel discharge did not exceed 1 percent of the discharge at the Coldbrook streamgage. A subset of Coldbrook daily-discharge data was selected for days when this condition was met: 6,874 daily-discharge values from October 1, 1931, to September 30, 2012. Natural discharge on these 6,874 days was calculated by subtracting the gaged daily discharge of the Shandaken Tunnel from the gaged daily discharge at Coldbrook. Natural discharge for the other 22,712 days during the 81-year period was estimated by applying a multiple regression approach as described in the following paragraphs.

Two multiple regression models were fit to Coldbrook discharge for the 6,874 days assumed to represent natural discharge. These regressions were then applied to estimate natural discharge on the 22,712 days on which Shandaken Tunnel discharge exceeded 1 percent of discharge at the streamgage. Daily-discharge values at nearby streamgages that are not greatly affected by either diversions or impoundment were selected as potential independent variables in the regression models. For the period from October 1, 1931, to February 3,1937, discharge data were available for two nearby streamgages, Schoharie Creek at Prattsville, N.Y. (01350000), and Beaver Kill at Cooks Falls, N.Y. (01420500). For the period from February 4, 1937, to September 30, 2012, discharge data for two additional gages were available for potential inclusion in the second multiple regression model: East Branch Delaware River at Margaretville, N.Y. (01413500), and Rondout Creek near Lowes Corners, N.Y. (01365000). Discharge values for the day before and the day after each day for which natural discharge was estimated were also explored as potential predictive variables in the regression. A few other streamgages in the region were explored for possible inclusion in models as well, but these sites showed weak relations to the daily discharge at the Coldbrook streamgage and were not considered further.

Multiple linear regression models were developed through use of a best subsets approach that explored all possible models for predicting natural flow at the Coldbrook streamgage with the combination of variables available for each of the two time periods. The final "best" models were chosen by examining fit metrics, including the standard error of estimate and the coefficient of determination $\left(\mathrm{R}^{2}\right)$. Parsimony was achieved by adding an additional independent variable to a model only if the adjusted $\mathrm{R}^{2}$ (Theil, 1961 ) increased by at least 0.02 . Independent variables were included in regression models only if the significance level ( $p$ value) was less than 0.05 and the variance inflation factor (a measure of multicollinearity) was less than 10. Models with comparable fit were then explored graphically for bias. Independent variables and the dependent variable were log (base 10) transformed, new regression models were calculated, and these models were compared with models developed with untransformed variables for improvement of fit and bias. Values derived from a regression model in which the dependent variable was log transformed were bias corrected by 
using a smearing estimator (Duan, 1983) before analysis and presentation.

The New York Streamflow Estimation Tool (NYSET) was used to estimate natural daily discharge for the watershed area between the Mount Marion and Coldbrook streamgages. This estimation was done by subtracting the daily discharge estimated by NYSET for the Coldbrook streamgage from the daily discharge estimated by NYSET for the Mount Marion streamgage. This difference was then added to the regressionestimated daily-discharge values that were derived for the Coldbrook streamgage (as described previously) to represent natural flow at the Mount Marion streamgage. This approach was considered superior to simply using the NYSET-estimated discharge at the Mount Marion streamgage because the multiple regression approach provided a better fit than NYSET to natural flow days at the Coldbrook streamgage.

NYSET was recently developed to estimate unaltered daily discharge at ungaged sites on streams and rivers in New York for the period from October 1, 1960, to September 30, 2010 (Gazoorian, 2015). NYSET can also be used to estimate natural discharge at gaged streams and rivers where discharge is affected by human water management activities. NYSET uses data from existing streamgages in New York to predict natural flow at an ungaged location or, as in this case, at a streamgage affected by water management (impoundment and withdrawal). Briefly, a reference gage is identified for the ungaged site through a geostatistical approach termed "map correlation" (Archfield and Vogel, 2010), and the flowduration value from the reference gage is assigned to each day for which an estimated flow is sought for the ungaged site. "Flow duration" refers to the number of days on which the daily flow is exceeded within a period of record (Foster, 1934); the period of WYs 1961 through 2010 was used in the development of NYSET. For example, a day whose flow was exceeded on 40 percent of the days during the period of record would have a flow-duration exceedance value of 40 percent; this is equivalent to a 60 -percentile value. The daily discharge was then estimated for 17 points along this hypothetical flow-duration curve on the basis of regression equations derived from 90 reference gages in New York, for which various basin characteristics, such as measures of slope, basin area, elevation, and precipitation, serve as dependent variables; the full suite of variables used in these regressions is described by Gazoorian (2015). In a final step, the full dailyflow record was filled between these 17 values through log-log interpolation. This approach, termed the QPPQ method, was specifically developed to estimate natural flow conditions in a river, and has been applied in Massachusetts and other states surrounding New York. Additional details of the method are described by Archfield and Vogel (2010) and Archfield and others (2010).

In this study, the Schoharie Creek at Prattsville streamgage was used as the reference gage to determine flow-duration values for the Esopus Creek because discharge at this site was the most strongly correlated with the Coldbrook streamgage over the entire study period for days when
Shandaken Tunnel discharge was minimal. An additional modification to the NYSET approach here was to extend the estimates back to October 1, 1931, and forward to September 30,2012 . This modification was consistent with the originally proposed study approach of providing an estimated natural flow record at the Mount Marion streamgage that extends from WY 1932 to WY 2012.

\section{Sources of Discharge Data}

Stream discharge data were obtained from the USGS New York Water Science Center Web site (U.S. Geological Survey, 2014b) for the entire periods of record at the Esopus Creek at Coldbrook (WYs 1932 through 2012) and the Esopus Creek at Mount Marion (WYs 1971 through 2012). Stream discharge data were obtained for the Schoharie Creek at Prattsville and the Beaver Kill at Cooks Falls streamgages for the period of WYs 1932 through 2012 and from the East Branch Delaware River at Margaretville and the Rondout Creek near Lowes Corners streamgages for the period from February 4, 1937, to September 30, 2012 (table 2). Additional data were obtained from the West Branch Delaware River at Walton (01423000), Neversink River near Claryville (01435000), and Esopus Creek at Allaben streamgages for WYs 1971 through 2012 to provide a comparison of gaged and natural annual runoff (discharge per unit basin area, reported in inches per year) at the Coldbrook and Mount Marion streamgages with the runoff of other regional streams (table 2). Finally, a dataset was assembled for the Shandaken Tunnel discharge to the Esopus Creek (diversion from Schoharie Reservoir, 01362230). Data before December 18, 1996 were obtained from records compiled by the New York City Department of Environmental Protection (J. Porter, New York City Department of Environmental Protection, written commun., 2014), and data for subsequent dates were obtained from USGS streamgage records.

Stream discharge was calculated from a stage-discharge rating curve according to methods described by Rantz and others $(1982 a, b)$. The USGS provides a general assessment of the accuracy of discharge data from a streamgage largely on the basis of the judgment of the hydrographer who processes the flow record each year. The accuracy categories are "excellent" (95 percent of daily values within 5 percent of actual discharge), "good" (95 percent of daily values within 10 percent of actual discharge), "fair" (95 percent of daily values within 15 percent of actual discharge) and "poor" (lower than "fair" quality). The flow records at the Esopus Creek streamgages at Coldbrook and Mount Marion are generally rated as "good," as are those of the Beaver Kill at Cooks Falls, East Branch Delaware River at Margaretville, West Branch Delaware River at Walton, and Neversink River near Claryville streamgages. In contrast, the streamgages at Schoharie Creek at Prattsville, Rondout Creek near Lowes Corners, and Esopus Creek at Allaben are generally rated as "fair." 
Table 2. Basin characteristics of seven streamgages that were used either as predictive variables in the estimation of natural discharge in the Esopus Creek at the Coldbrook, New York, streamgage or in calculations of annual runoff for comparison with gaged and natural runoff in the Esopus Creek at Coldbrook and Mount Marion, N.Y., streamgages.

[Data from U.S. Geological Survey (2014a). Ck., Creek; N.Y., New York; E., East; R., River; W., West; USGS, U.S. Geological Survey; ID, identification number]

\begin{tabular}{|c|c|c|c|c|c|c|c|}
\hline \multirow[t]{2}{*}{$\begin{array}{c}\text { Basin } \\
\text { characteristics }\end{array}$} & \multicolumn{7}{|c|}{ Streamgage } \\
\hline & $\begin{array}{l}\text { Schoharie } \\
\text { Ck. at } \\
\text { Prattsville, } \\
\text { N.Y. }\end{array}$ & $\begin{array}{l}\text { Beaver Kill } \\
\text { at Cooks } \\
\text { Falls, N.Y. }\end{array}$ & $\begin{array}{c}\text { E. Branch } \\
\text { Delaware R. at } \\
\text { Margaretville, } \\
\text { N.Y. }\end{array}$ & $\begin{array}{l}\text { Rondout Ck. } \\
\text { near Lowes } \\
\text { Corners, } \\
\text { N.Y. }\end{array}$ & $\begin{array}{l}\text { W. Branch } \\
\text { Delaware R. } \\
\text { at Walton, } \\
\text { N.Y. }\end{array}$ & $\begin{array}{l}\text { Neversink } \\
\text { R. near } \\
\text { Claryville, } \\
\text { N.Y. }\end{array}$ & $\begin{array}{l}\text { Esopus Ck. at } \\
\text { Allaben, N.Y. }\end{array}$ \\
\hline USGS streamgage ID & 01350000 & 01420500 & 01413500 & 01365000 & 01423000 & 01435000 & 01362200 \\
\hline $\begin{array}{l}\text { Mean basin slope, } \\
\text { in percent }\end{array}$ & 20.7 & 17.8 & 23.1 & 27.9 & 18.1 & 22.7 & 31.5 \\
\hline $\begin{array}{l}\text { Basin storage }^{1}, \\
\text { in percent }\end{array}$ & 0.54 & 1.3 & 0.17 & 0.08 & 0.30 & 0.09 & 0.03 \\
\hline $\begin{array}{l}\text { Mean annual runoff, in } \\
\text { inches, 1951-1980 }\end{array}$ & 27.5 & 30.5 & 27.6 & 34.0 & 24.6 & 37.5 & 33.5 \\
\hline $\begin{array}{l}\text { Mean annual } \\
\text { precipitation, in } \\
\text { inches, 1951-1980 }\end{array}$ & 46.8 & 49.1 & 46.3 & 51.7 & 44.0 & 55.4 & 52.4 \\
\hline
\end{tabular}

${ }^{1}$ Percentage of total area in lakes, ponds, and wetlands.

\section{Analyses of Discharge Data}

The estimated records of natural daily discharge at the Esopus Creek at Coldbrook and Mount Marion streamgages were compared to the daily gage records affected by tunnel discharge and impoundment, respectively. First, the cumulative percentage of days throughout the study period on which the flow was exceeded was calculated for each record as a basis for comparing natural and gaged flow-duration or exceedance values. Second, the Indicators of Hydrologic Alteration (IHA) software was applied to calculate several high-flow and low-flow metrics (table 3) as a basis for further comparisons between the natural and gaged discharge records (Richter and others, 1996). Comparisons of estimated natural and human-influenced daily discharge were made for the Coldbrook streamgage for WYs 1932 through 2012, whereas comparisons for the Mount Marion streamgage were for WYs 1971 through 2012 to encompass the maximum number of full water years available (the Mount Marion record began March 1, 1970). Flow metrics were also calculated by using IHA for the estimated natural daily discharge at the Mount Marion streamgage for WYs from 1932 through 2012 to facilitate comparisons with the estimated natural discharge record at the Coldbrook streamgage. Finally, annual runoff was calculated for seven streamgage sites in the Catskills that were not affected by impoundment during WYs 1932 through 2012 and WYs 1971 through 2012 for comparing to the gaged and natural annual runoff at the Coldbrook and Mount Marion streamgages.

\section{Estimated Natural Discharge Results}

Results for two multiple linear regression equations developed to estimate natural discharge at the Coldbrook streamgage are described along with the ability of these regressions to predict natural flow in the Esopus Creek. The resulting natural discharge estimates for the Coldbrook streamgage are then compared with gaged discharge throughout the range of flow at this site, including several low-flow and high-flow metrics. A similar comparison is then made between natural discharge estimates and gaged discharge for the Esopus Creek at Mount Marion streamgage. Finally, the natural estimates of discharge and gaged discharge at the two Esopus Creek sites are compared with discharge at several nearby Catskill region streamgages through calculation of mean annual runoff.. 
Table 3. Description of flow metrics calculated by the Indicators of Hydrologic Alteration software for each discharge record analyzed in this study.

[Mean values were calculated for each period of record analyzed]

\begin{tabular}{ll}
\hline \multicolumn{1}{c}{ Flow metric } & \multicolumn{1}{c}{ Description } \\
\hline 1-day minimum flow & Annual 1-day minimum daily discharge \\
3-day minimum flow & Annual consecutive 3-day minimum daily discharge \\
7-day minimum flow & Annual consecutive 7-day minimum daily discharge \\
30-day minimum flow & Annual consecutive 30-day minimum daily discharge \\
90-day minimum flow & Annual consecutive 90-day minimum daily discharge \\
1-day maximum flow & Annual 1-day maximum daily discharge \\
3-day maximum flow & Annual consecutive 3-day maximum daily discharge \\
7-day maximum flow & Annual consecutive 7-day maximum daily discharge \\
30-day maximum flow & Annual consecutive 30-day maximum daily discharge \\
90-day maximum flow & Annual consecutive 90-day maximum daily discharge \\
\hline
\end{tabular}

\section{Regression Models for Estimating Natural Discharge at the Coldbrook Streamgage}

Two different multiple regression models were developed to predict natural discharge at the Coldbrook streamgage. From October 1, 1931, through February 3, 1937, the beginning of the period for which estimations were made, only two nearby discharge records were available as independent variables in a regression: Schoharie Creek at Prattsville and Beaver Kill at Cooks Falls. A regression model with two independent variables was selected as having the best fit and least predictive bias while meeting the conditions of acceptability as described in the methods section. Log transformation of the variables improved the fit and bias, and therefore, a model with log-transformed variables was selected.

The equation for this regression model is

$\log$ Coldbrook $=0.0568+(0.418 \times \log$ Cooks $)+(0.553 \times \log$

Prat),

where

$\log$ Coldbrook is the log base 10 of the predicted natural discharge at the Coldbrook streamgage (equation was fit to Coldbrook discharge minus Shandaken Tunnel discharge),

log Cooks is the log base 10 of discharge at the Beaver

Kill at Cooks Falls streamgage, and

log Prat is the log base 10 of discharge at the

Schoharie Creek at Prattsville streamgage.

All discharge values are in units of cubic feet per second. This regression model was based on 6,874 days during WYs 1932 through 2012 on which discharge at the Coldbrook streamgage minus the Shandaken Tunnel discharge was less than 1 percent of the Coldbrook streamgage discharge. The adjusted $\mathrm{R}^{2}$ value of this model is 0.931 , and both independent variables are highly significant $(p<0.001)$. The predicted discharge values of this regression are shown relative to the Coldbrook streamgage minus Shandaken Tunnel discharge values in figure $2 A$. Because this regression was developed with log-transformed data, the uncertainty as reflected by the 95-percent prediction intervals is not symmetrical about the regression line and varies in untransformed discharge units throughout the full range of flow at this site. However, the prediction intervals are approximately constant relative to the predicted discharge, and vary by about +79 percent and -44 percent throughout the flow range at the Coldbrook streamgage. These results highlight the limitations of using the regression model developed to predict natural discharge on any individual day. Although the multiple regression model to estimate natural flow at the Coldbrook streamgage is highly significant and can account for about 93 percent of the variation in the full set of days when the tunnel did not impact streamflow, the model cannot predict discharge with high accuracy on any particular day, and these results should be applied on a daily basis with caution.

The second multiple regression model to represent natural flow at the Coldbrook streamgage was developed for the period from February 4, 1937, through September 30, 2012, when in addition to the Schoharie Creek at Prattsville and the Beaver Kill at Cooks Falls streamgages, two additional nearby flow records were available for the Rondout Creek near Lowes Corners and the East Branch Delaware River at Margaretville (not used in final predictive regressions). A multiple regression model with three independent variables was selected as having the best fit and least predictive bias while meeting the conditions of acceptability (as described in the methods section). 
A. Discharge predictions from regression, 1932-2012

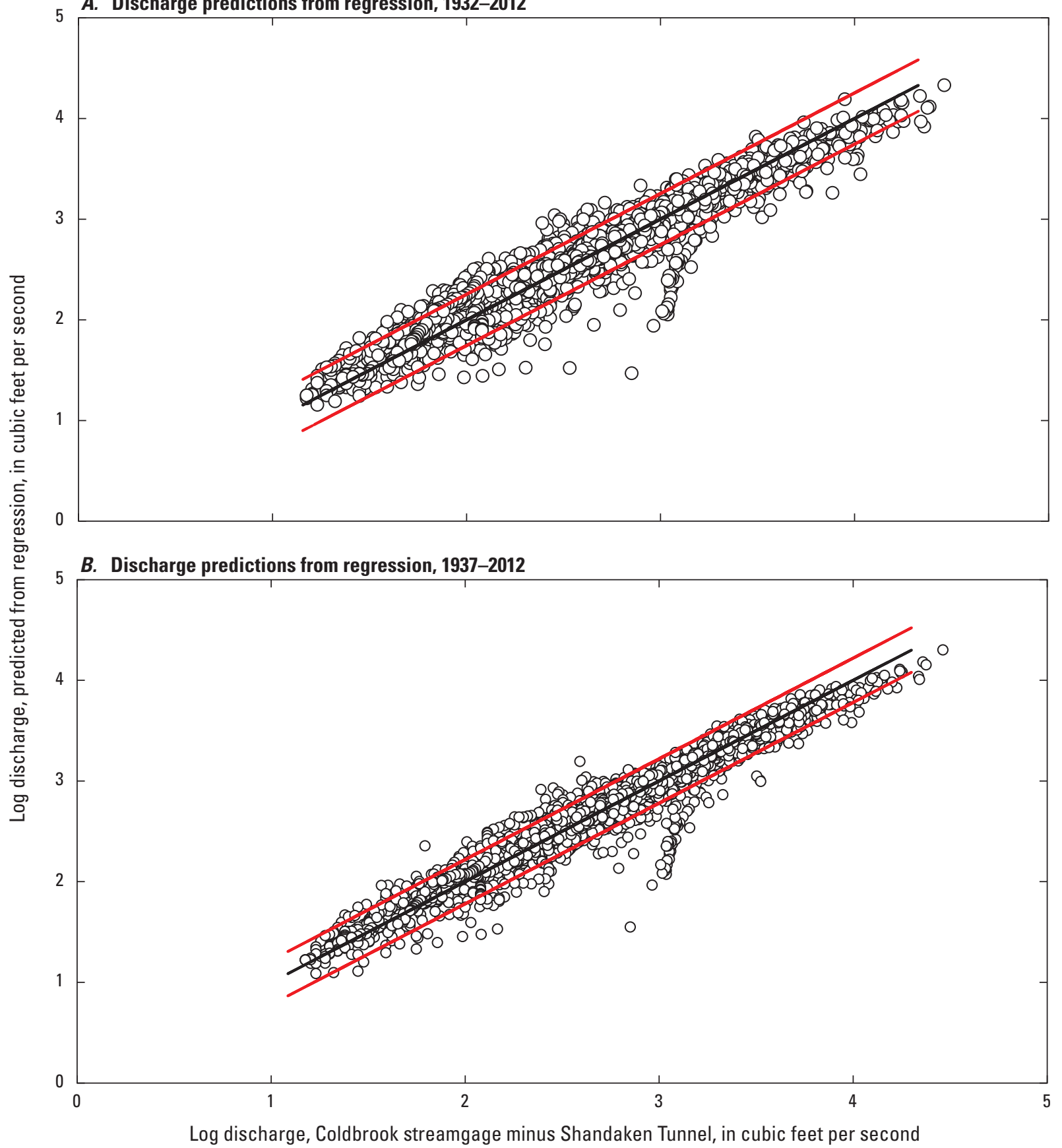

Figure 2. Daily-discharge values predicted by two multiple regression models applied to estimate natural daily discharge at the Esopus Creek at Coldbrook streamgage (01362500) from October 1, 1931, to September 30, 2012. Discharge values predicted by the regressions are shown relative to the difference of Coldbrook streamgage discharge and Shandaken Tunnel discharge for days when Tunnel discharge was less than 1 percent of Coldbrook streamgage discharge. The solid black line represents the regression relation, and the two red lines indicate the upper and lower limits for the 95-percent prediction intervals of the regression relation. A, Gaged and regression-derived values for the period from October 1, 1931, to September 30, 2012, shown for 6,874 days when the discharge at the Coldbrook streamgage was assumed to represent natural flow conditions. This regression was applied to estimate natural discharge at the Coldbrook streamgage for days from October 1, 1931, to February 3, 1937, when gaged discharge did not represent natural flow conditions. B, Gaged and regression-derived values from February 4, 1937, to September 30, 2012, shown for 6,298 days when the discharge at the Coldbrook streamgage was assumed to represent natural flow conditions. This regression was applied to estimate natural discharge at the Coldbrook streamgage for days from February 4, 1937, to September 30, 2012, when gaged discharge did not represent natural flow conditions. 
Improved fit and bias were achieved by log-transforming the dependent and independent variables.

The equation for this regression model is

$\log$ Coldbrook $=0.263+(0.430 \times \log$ Prat $)+(0.525 \times \log$

Rondout $)+(0.0744 \times \log$ Cooks -1$)$,

where

$\log$ Coldbrook is the log base 10 of the predicted natural discharge at the Coldbrook streamgage (equation was fit to Coldbrook discharge minus Shandaken Tunnel discharge),

$\log$ Prat is the log base 10 of the discharge at the Schoharie Creek at Prattsville streamgage,

$\log$ Rondout is the $\log$ base 10 of the discharge at the Rondout Creek near Lowes Corners streamgage, and

$\log$ Cooks-1 is log base 10 of the discharge at the Beaver Kill at Cooks Falls streamgage on the day preceding the day for which predictions were made.

All discharge values are in units of cubic feet per second. This regression model was based on 6,298 days during the period on which the discharge at the Coldbrook streamgage minus the Shandaken Tunnel discharge was less than 1 percent of the Coldbrook streamgage discharge. The adjusted $\mathrm{R}^{2}$ value of this model was 0.946 , and all three independent variables were highly significant $(\mathrm{p}<0.001)$. The predicted discharge values of this regression are shown relative to the difference of the Coldbrook streamgage discharge and the Shandaken Tunnel discharge in figure $2 B$. Because this regression was developed with log-transformed data, the uncertainty in predictions is not symmetrical about the regression line and varies in untransformed discharge units throughout the full range of flow at this site. However, the prediction intervals are approximately constant relative to the predicted flow, and vary by about +66 percent and -40 percent throughout the flow range at the Coldbrook streamgage.

\section{Comparison of Estimated Natural Discharge and Gaged Discharge at the Coldbrook Streamgage}

Daily-discharge values at the Coldbrook streamgage were used directly to represent natural daily discharge in the Esopus Creek on days when the Shandaken Tunnel discharge was less than 1 percent of the discharge at the streamgage, which occurred on 6,874 days, or 23.2 percent of the days throughout the full study period. To estimate natural discharge for the remaining 76.8 percent of the daily record, the two regression models discussed in the previous section were applied to predict daily-discharge values: the first regression for the period from October 1, 1931, to February 3, 1937, and the second regression for the period from February 4, 1937, to September 30,2012. The complete record of estimated natural daily discharge was then compared with the Coldbrook streamgage daily-discharge record through flow-duration curves and several high-flow and low-flow statistics computed by using IHA.

The estimated natural daily discharge at the Coldbrook streamgage was less than the gaged daily discharge throughout the flow range, and the mean difference peaked in the 10- to 20-percent flow-exceedance range (fig. 3; table 4). The mean difference declined gradually through the 80 - to 90 -percent flow-exceedance range before dropping off sharply thereafter. The mean difference also declined fairly sharply and by nearly half from the 10- to 20-percent flow-exceedance range to the 0 - to 1-percent flow-exceedance range. The mean relative difference between the Coldbrook gaged discharge and estimated natural discharge shows a different pattern of change than that of the mean difference, with the mean relative difference peaking in the 80- to 90-percent flow-exceedance range and sharply declining to the 99- to 100-percent flow-exceedance range. The mean relative difference also decreased gradually and successively from the 80- to 90-percent flow-exceedance range to the 10- to 20-percent flow-exceedance range and then decreased sharply to the 0 - to 1 -percent flow-exceedance range. The gaged discharge exceeded the estimated natural discharge for Coldbrook streamgage by a mean of 4.3 percent for the highest 1 percent of flows. The low-flow metrics calculated by IHA indicate that the Coldbrook gaged discharge was $66.8 \mathrm{ft}^{3} / \mathrm{s}$ greater than the estimated natural discharge for the 1-day annual minimum flow, and this value increased successively and by more than threefold to $227.9 \mathrm{ft}^{3} / \mathrm{s}$ for the 90 -day annual minimum flow (table 5). Gaged discharge at the Coldbrook streamgage was consistently about three times greater than natural flow estimates throughout the low-flow range shown in table 5 . The relative differences between these two records for the high-flow metrics are much smaller than those calculated for the low-flow metrics, indicating that the relative influence of the Shandaken Tunnel on Esopus Creek discharge

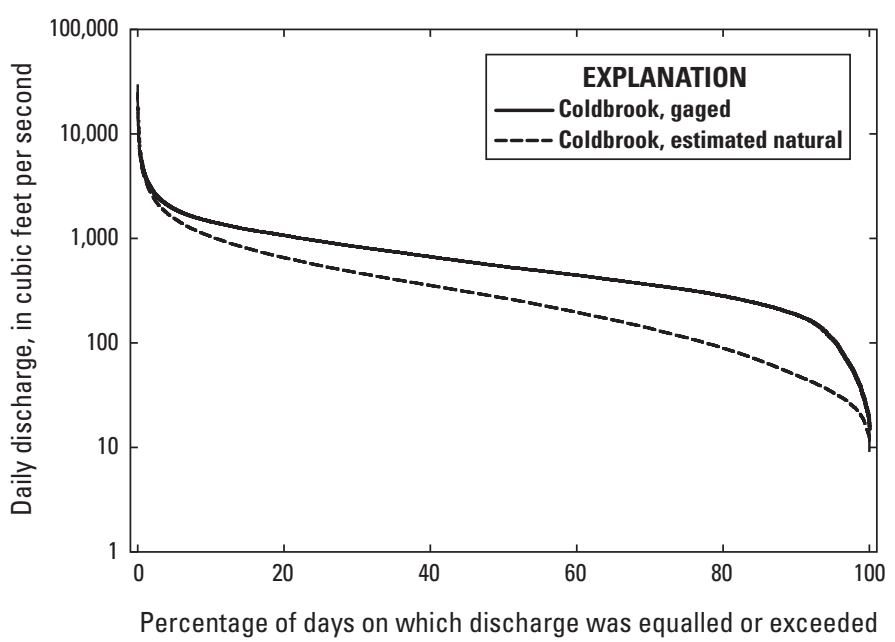

Figure 3. Flow-duration curves based on gaged daily discharge and natural daily-discharge estimates for the Coldbrook streamgage (01362500) from October 1, 1931, to September 30, 2012. 
Table 4. Range of gaged daily discharge and natural daily-discharge estimates as well as mean relative difference between these values as a function of flow exceedance range for the Coldbrook, New York, streamgage (01362500) from 0ctober 1, 1931, to September 30, 2012.

$\left[\mathrm{ft}^{3} / \mathrm{s}\right.$, cubic feet per second]

\begin{tabular}{|c|c|c|c|c|}
\hline $\begin{array}{c}\text { Flow-exceedance range, } \\
\text { in percent }\end{array}$ & $\begin{array}{c}\text { Gaged daily discharge } \\
\text { across exceedance } \\
\text { range, } \\
\text { in } \mathrm{ft}^{3} / \mathrm{s}\end{array}$ & $\begin{array}{c}\text { Natural daily-discharge } \\
\text { estimates across exceed- } \\
\text { ance range, } \\
\text { in } \mathrm{ft}^{3} / \mathrm{s}\end{array}$ & $\begin{array}{c}\text { Mean Discharge Differ- } \\
\text { ence }\left(\mathrm{ft}^{3} / \mathrm{s}\right)\end{array}$ & $\begin{array}{c}\text { Mean relative difference, } \\
\text { as percentage of natural } \\
\text { discharge }\end{array}$ \\
\hline $90-100$ & $185-9.3$ & $49.1-11.6$ & +71.6 & +193.7 \\
\hline $70-80$ & $360-280$ & $138-88.9$ & +208.6 & +187.6 \\
\hline $60-70$ & $444-360$ & $196-138$ & +234.4 & +142.3 \\
\hline $50-60$ & $538-444$ & 269-196 & +257.3 & +111.9 \\
\hline $40-50$ & $665-538$ & $354-269$ & +288.6 & +93.6 \\
\hline $10-20$ & $1,440-1,070$ & $1,040-653$ & +413.6 & +51.6 \\
\hline $0-10$ & $29,030-1,440$ & $29,015-1,040$ & +339.5 & +22.1 \\
\hline $0-1$ & $29,030-3,901$ & $29,015-3,750$ & +228.7 & +4.3 \\
\hline
\end{tabular}

Table 5. Gaged daily discharge and estimated natural daily discharge as well as the difference and relative differences between these values as a function of mean annual flow metrics for consecutive-day low-flow and high-flow days for the Coldbrook, New York, streamgage (01362500) from October 1, 1931, to September 30, 2012.

$\left[\mathrm{ft}^{3} / \mathrm{s}\right.$, cubic feet per second]

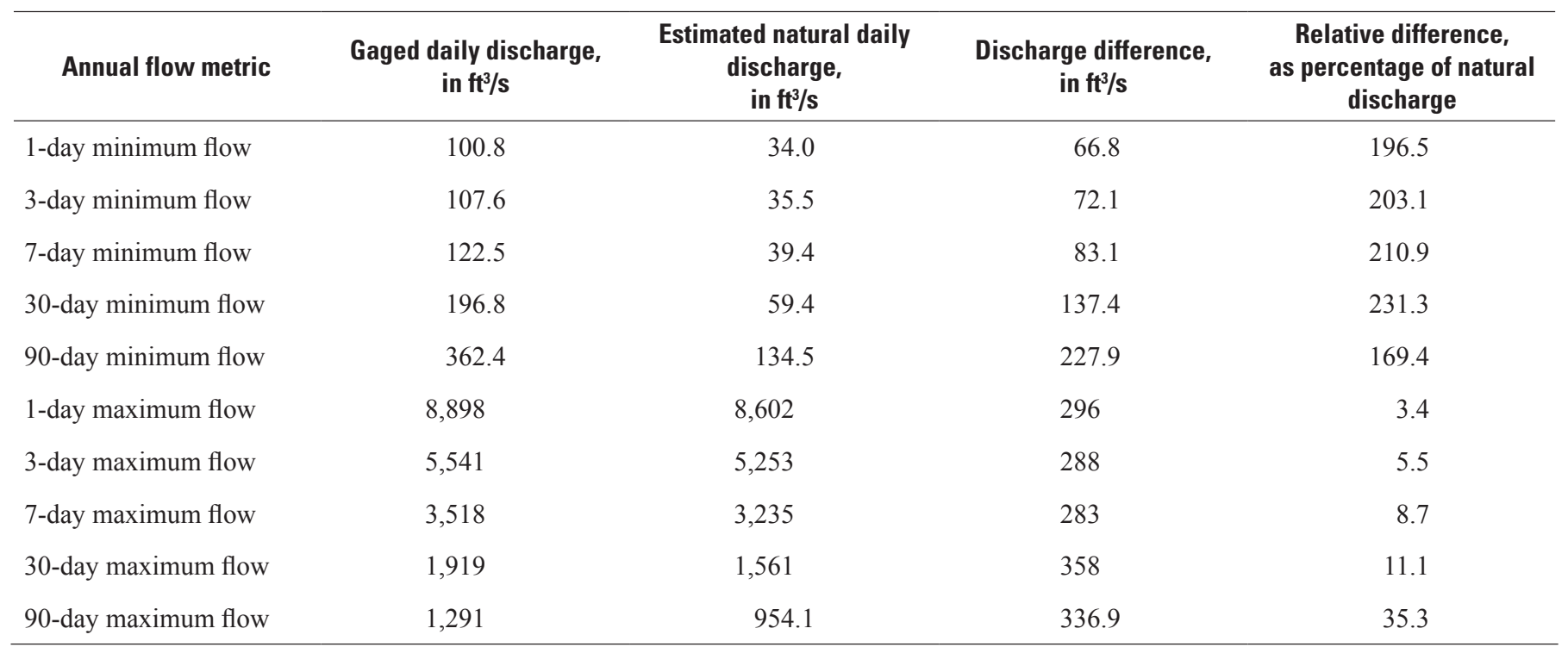


is substantially less at high flow. Although the differences in discharge between these two records are greater at high flow, the relative differences in discharge are much greater at low flow.

\section{Comparison of Estimated Natural Discharge and Historical Discharge at the Mount Marion Streamgage}

The estimated natural daily discharge at the Mount Marion streamgage, developed by summing the estimated natural daily discharge at the Coldbrook streamgage and the NYSET-estimated natural daily discharge for the intervening area between Coldbrook and Mount Marion streamgages, was compared with the gaged daily discharge at the Mount Marion streamgage for the period from October 1, 1970, to September 30, 2012. The gaged discharge at the Mount Marion streamgage was less than the estimated discharge throughout the full range of flow conditions during WYs 1971 through 2012 (fig. 4). The mean difference in discharge between these two flow records increased with increasing flow and decreasing flow exceedance value (table 6). The mean difference in discharge ranged from $21.5 \mathrm{ft}^{3} / \mathrm{s}$ in the 99 - to 100 -percent flow-exceedance range and increased successively to a value of $3,221 \mathrm{ft}^{3} / \mathrm{s}$ in the 0 - to 1 -percent flow-exceedance range.

The gaged discharge at Mount Marion streamgage was about two-thirds less than that of the estimated natural

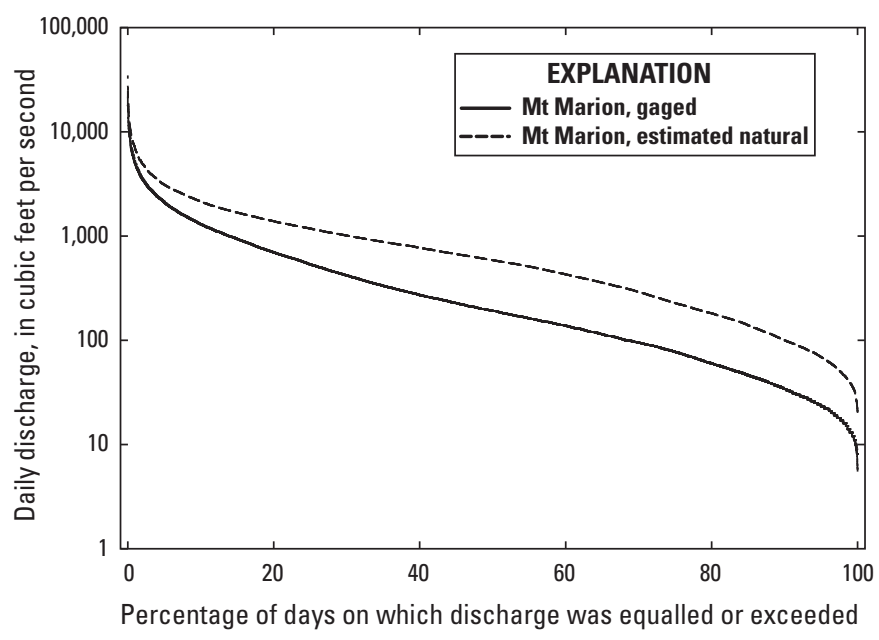

Figure 4. Flow-duration curves based on gaged daily discharge and natural daily-discharge estimates for the Mount Marion streamgage (01364500) from October 1, 1970, to September 30, 2012.

discharge throughout the 40- to 100-percent flow-exceedance range, and this difference narrowed successively to 27.7 percent less in the flow-exceedance range of 0 to 1 percent. These high-flow results are consistent with previous observations that the Ashokan Reservoir and other reservoirs in the Catskills operated by the New York City Department of

Table 6. Range of gaged daily discharge and natural daily-discharge estimates as well as mean relative difference of these values as a function of flow exceedance values for the Mount Marion, New York, streamgage (01364500) from 0ctober 1, 1970, to September 30, 2012.

$\left[\mathrm{ft}^{3} / \mathrm{s}\right.$, cubic feet per second]

\begin{tabular}{|c|c|c|c|c|}
\hline $\begin{array}{c}\text { Flow exceedance range, } \\
\text { in percent }\end{array}$ & $\begin{array}{c}\text { Gaged daily discharge } \\
\text { across exceedance } \\
\text { range, } \\
\text { in } \mathrm{ft}^{3} / \mathrm{s}\end{array}$ & $\begin{array}{l}\text { Natural daily discharge } \\
\text { estimates across exceed- } \\
\text { ance range, in } \mathrm{ft}^{3} / \mathrm{s}\end{array}$ & $\begin{array}{c}\text { Mean Discharge Differ- } \\
\text { ence } \\
\left(\mathrm{ft}^{3} / \mathrm{sec}\right)\end{array}$ & $\begin{array}{c}\text { Mean relative difference, } \\
\text { as percentage of natural } \\
\text { discharge }\end{array}$ \\
\hline 99-100 & $13-5.6$ & $30-17$ & -21.5 & -66.5 \\
\hline $90-100$ & $34-5.6$ & $75-17$ & -44.6 & -66.0 \\
\hline $70-80$ & $95-60$ & $212-129$ & -153.4 & -66.5 \\
\hline $60-70$ & $138-95$ & $316-212$ & -243.3 & -68.0 \\
\hline $50-60$ & $191-138$ & $437-316$ & -345.2 & -68.0 \\
\hline $40-50$ & $270-191$ & $588-437$ & -445.6 & -66.2 \\
\hline $10-20$ & $1,290-696$ & $1,821-1,149$ & -752.4 & -44.6 \\
\hline $0-10$ & $24,200-1,290$ & $46,237-1,821$ & $-1,310$ & -33.2 \\
\hline $0-1$ & $24,200-4,979$ & $46,237-6,173$ & $-3,221$ & -27.7 \\
\hline
\end{tabular}


Table 7. Gaged daily discharge and estimated natural daily discharge as well as the difference and relative difference of these values as a function of mean annual flow metrics for consecutive-day low-flow and high-flow days for the Mount Marion streamgage (01364500) from October 1, 1970, to September 30, 2012.

[ $\mathrm{ft}^{3} / \mathrm{s}$, cubic feet per second]

\begin{tabular}{lcccc}
\hline Annual flow metric & $\begin{array}{c}\text { Gaged daily discharge, } \\
\text { in ft3 } / \mathbf{s}\end{array}$ & $\begin{array}{c}\text { Estimated natural daily } \\
\text { discharge, } \\
\text { in ft3 } / \mathbf{s}\end{array}$ & $\begin{array}{c}\text { Discharge difference, } \\
\text { in ft/s }\end{array}$ & $\begin{array}{c}\text { Relative difference, } \\
\text { as percentage of natu- } \\
\text { ral discharge }\end{array}$ \\
\hline 1-day minimum flow & 22.4 & 67.8 & 45.4 & -67.0 \\
3-day minimum flow & 23.3 & 71.0 & 47.7 & -67.2 \\
7-day minimum flow & 25.9 & 80.4 & 54.5 & -67.8 \\
30-day minimum flow & 41.8 & 122.2 & 80.4 & -65.8 \\
90-day minimum flow & 114.8 & 277.4 & 162.6 & -58.6 \\
1-day maximum flow & 8,307 & 14,540 & 6,233 & -42.9 \\
3-day maximum flow & 6,393 & 8,938 & 2,545 & -28.5 \\
7-day maximum flow & 4,193 & 5,624 & 1,431 & -25.4 \\
30-day maximum flow & 1,974 & 2,916 & 942 & -32.3 \\
90-day maximum flow & 1,166 & 1,880 & 714 & -38.0 \\
\hline
\end{tabular}

Environmental Protection, though not designed as flood-control reservoirs, decrease downstream flood peaks substantially (Zembrzuski and Evans, 1989; Suro and Firda, 2007; Milone and MacBroom, Inc., 2009). The analysis by Milone and MacBrook, Inc. (2009) indicated that instantaneous flood peaks are reduced by about 60 percent as a result of the emplacement of the Ashokan Reservoir. In contrast, the current analysis indicates that the 1-day annual maximum daily discharge was diminished by a lower mean value of about 43 percent during WYs 1971 through 2012. The higher diminishment value from the analysis in Milone and MacBrook, Inc.(2009) may reflect the report's basis on only 5 instantaneous peaks,

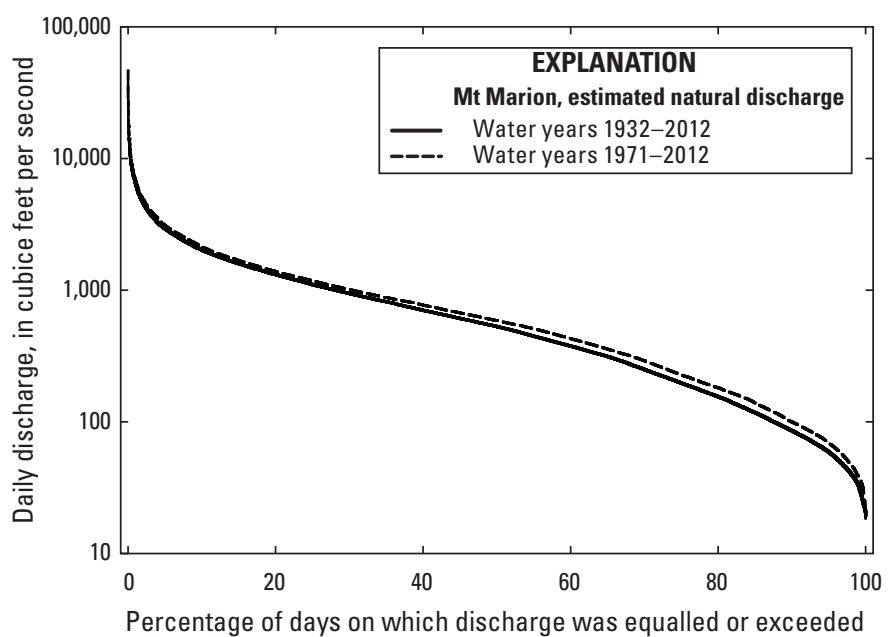

whereas the analysis in this report reflects 1-day annual values based on 43 peak-flow days. Streamgage remarks from the National Water Information System (U.S. Geological Survey, 2014c) as well as the analysis of Milone and MacBroom, Inc. (2009) describe the natural discharge at the Mount Marion streamgage as representative of an effective watershed area of $112 \mathrm{mi}^{2}$ during nonflood conditions, whereas the analysis in this report indicates a value of about one-third of the drainage area, or $140 \mathrm{mi}^{2}$.

The annual low-flow metrics showed a similar pattern to those of the flow-exceedance values (table 7). The Mount Marion streamgage discharge was about two-thirds less than

Figure 5. Flow-duration curves based on natural daily-discharge estimates for the Mount Marion streamgage (01364500) from October 1, 1931, to September 30, 2012, and from October 1, 1970, to September 30, 2012. 
the estimated natural discharge for the 1-day, 3-day, 7-day, and 30-day annual minimum flows and decreased slightly to 58.6 percent less for the 90 -day annual minimum flow. At high flow, the relative differences in flow were less than those at low flow; relative differences at high flow ranged from 25.4 to 42.9 percent less than the estimated natural discharge for the five metrics for annual maximum flow, and the greatest relative difference was for the annual 1-day maximum flow.

Natural discharge was also estimated for the period of WYs 1932 through 2012 for the Mount Marion streamgage. The estimated natural discharge values for this period were lower than the exceedance values for the previously computed period of WYs 1971 through 2012 (fig. 5). The differences between these estimates, however, were smaller than the differences previously described for comparisons of the effects of Shandaken Tunnel discharge on Coldbrook streamgage discharge and the effects of impoundment of the Ashokan Reservoir on the Mount Marion streamgage discharge. For example, the estimated natural discharge at the Mount Marion streamgage for WYs 1971 through 2012 was 17.0 percent greater than the estimated natural discharge for WYs 1932 through 2012 at 90-percent flow exceedance, 11.1 percent greater at 50-percent flow exceedance, and 6.3 percent greater at 10-percent flow exceedance.

\section{Comparison of Natural Annual Runoff Estimates for the Coldbrook and Mount Marion Streamgages with Annual Runoff at Nearby Catskill Streamgages}

Mean annual runoff values from several streamgages operated by the USGS in the Catskill Mountain region were compared with values computed from the gaged and natural daily discharge at the Coldbrook and Mount Marion streamgages. Only streamgages upstream of the New York City water-supply reservoirs were chosen for this analysis to minimize the effects of impoundment and therefore provide a stronger basis for comparison. The comparisons were made for two periods-from October 1, 1931, to September 30, 2012, and from October 1, 1970, to September 30, 2012 - to include as many complete water years as possible within the full periods of record for the Coldbrook and Mount Marion streamgages, respectively. The data indicate a wide range of natural variation in annual runoff in streams of this region. Across both time periods examined, mean annual runoff at the regional streamgages ranged from 26.3 in at the West Branch Delaware River at Walton streamgage to 42.3 in at the Neversink River near Claryville streamgage (table 8). Mean annual runoff values at the two streamgages affected by flow alteration that resulted from New York City's water-supply activities were outside this range of natural variation. Mean annual runoff was 53.5 in at the Esopus Creek at Coldbrook streamgage during WYs 1932 through 2012 (and 53.0 in during WYs 1971 through 2012), whereas mean annual runoff at the Esopus Creek at Mount Marion streamgage was 17.2 in during WYs 1971 through 2012. In contrast, the estimated annual natural runoff during the same two periods was 34.4 in. and $37.1 \mathrm{in}$., respectively, at the Coldbrook streamgage and 29.6 and 32.0 in, respectively, at the Mount Marion streamgage. These results show that estimation of natural flow in the Esopus Creek shifted annual runoff values from being the highest (Coldbrook) and lowest (Mount Marion) in the region to being well within the range of natural variation observed for Catskill region streams. These natural runoff estimates are greater than those provided in table 1, which are based on the analysis of Randall (1996) for the period of 1951 through 1980.

The difference between mean annual runoff and the mean annual estimated natural runoff for the Coldbrook streamgage provides an estimate of the extent to which Shandaken Tunnel discharge increases natural flow in the Esopus Creek. During WYs 1932 through 2012, the difference was 19.1 in., compared with a mean annual runoff value of $20.7 \mathrm{in}$. based on the gaged discharge of the Shandaken Tunnel for the same period (table 8). During WYs 1971 through 2012, the calculated difference was $15.9 \mathrm{in}$., whereas the value based on gaged Shandaken Tunnel discharge was $18.2 \mathrm{in.}$

\section{Effects of Discharge Through the Shandaken Tunnel on the Interaction of Esopus Creek With Alluvial Groundwater}

The originally proposed study approach was to estimate natural discharge at the Coldbrook streamgage by subtracting the daily Shandaken Tunnel discharge from the daily discharge at the streamgage. This approach did not provide accurate estimates of natural daily discharge at Coldbrook. This proposed calculation would be appropriate if the Esopus Creek behaved like a pipe, transferring all of the discharge from the Shandaken Tunnel in one day to the streamgage at Coldbrook, but the data show that the creek did not consistently behave like a pipe along the approximately 10.5 -mi reach between the two measurement sites (fig. 6). Additionally, a lag is likely between the time when water is discharged from the Shandaken Tunnel and when this discharge is detected at the Coldbrook streamgage, $10.5 \mathrm{mi}$ downstream. This lag is expected to vary according to stream velocity and resulting traveltimes, but a value as high as half a day to 2 days is likely based on typical stream velocities measured at the Coldbrook streamgage.

Figure 6 provides examples of two periods in which the daily discharge of the Shandaken Tunnel exceeded that at the Coldbrook streamgage, resulting in negative values of natural daily discharge when calculated by the subtraction approach, an unrealistic situation. Negative discharge values resulted for 12 days during July 1966 (fig. 6A) and 3 days during August 1965 (fig. 6B). Negative daily discharge during these two periods reached values of $-114.5 \mathrm{ft}^{3} / \mathrm{s}$ on July 18,1966 , and $-85.5 \mathrm{ft}^{3} / \mathrm{s}$ on August 14, 1965. The magnitude of these calculated negative discharge values suggest that they did not likely result solely from uncertainty in the two discharge measures. 
Table 8. Mean annual runoff based on gaged and estimated natural daily discharge at the Coldbrook, New York (01362500), and Mount Marion, N.Y. (01364500), streamgage sites along with mean annual runoff for three other gaged sites in the Catskill Mountain region from October 1, 1931, to September 30, 2012, and seven other gaged sites from October 1, 1970, to September 30, 2012. Annual runoff values are expressed in inches.

[--, no data]

Streamgage site or flow record

\begin{tabular}{lcc}
\hline \multicolumn{1}{c}{ Streamgage site or flow record } & \multicolumn{2}{c}{ Mean annual runoff, in inches } \\
\hline & October 1, 1931- & October 1, 1970- \\
September 30, 2012 \\
Esopus Creek at Coldbrook gaged discharge & 53.5 & 53.0 \\
Esopus Creek at Coldbrook natural discharge & 34.4 & 37.1 \\
Esopus Creek at Mount Marion gaged discharge & -- & 17.2 \\
Esopus Creek at Mount Marion natural discharge & 29.6 & 32.0 \\
Esopus Creek at Allaben (01362200) gaged discharge & -- & 34.3 \\
Schoharie Creek at Prattsville (01350000) gaged discharge ${ }^{1}$ & 27.8 & 30.6 \\
Beaver Kill at Cooks Falls (01420500) gaged discharge & 32.4 & 34.8 \\
Rondout Creek near Lowes Corners (01365000) gaged discharge & -- & 39.1 \\
East Branch Delaware River at Margaretville (01413500) gaged discharge & -- & 28.3 \\
West Branch Delaware River at Walton (01423000) gaged discharge $_{\text {Neversink River near Claryville (01435000) gaged discharge }}$ & -- & 26.3 \\
Shandaken Tunnel $^{2}$ & -- & 42.3 \\
\hline
\end{tabular}

${ }^{1}$ Discharge was affected by withdrawals for snowmaking during winter.

${ }^{2}$ Runoff was calculated by dividing tunnel discharge by the drainage area of the Esopus Creek at Coldbrook streamgage.

Shandaken Tunnel discharge exceeded that at the Coldbrook streamgage on 1,503 days during water years (WYs) 1932 through 2012, about 5.1 percent of the total days.

On many days, this difference calculation did not yield negative values but still provided unrealistically low estimates of natural discharge for the Esopus Creek at Coldbrook. For example, between August 13, 1965, and August 15, 1965, the estimated difference was less than the discharge measured at the upstream Esopus Creek at Allaben, N.Y., streamgage (01362200), a site that drains a watershed only one-third the size of the watershed at Coldbrook (fig. 6B). An additional consideration is that the drainage area of the Esopus Creek where the Shadaken Tunnel enters is $67.2 \mathrm{mi}^{2}$, much smaller than the drainage area of $192 \mathrm{mi}^{2}$ at the Coldbrook streamgage, and many tributaries enter the Creek along the 10.5-mi reach between the two sites. If the contributions of all inflows to Esopus Creek are considered, then many additional days are likely for which subtraction of these two flow records would yield unrealistically low values.

The calculated difference between the Shandaken Tunnel discharge and that of the Coldbrook streamgage also seemed to be unrealistically high for many days. For example, during August 14-18, 1965, this calculated difference increased during a period when flows on the Esopus Creek (as shown by the Allaben streamgage) were generally receding (fig. 6B).
The evidence of unrealistically low and high daily discharge values when calculated by the originally proposed subtraction approach suggest that the Esopus Creek channel does not behave like a pipe and that, instead, streamflow likely reflects dynamic interaction between stream water and the streambanks and flood plain, which in the Esopus valley generally consist of permeable sand and gravel deposits (Rich, 1935). Dynamic interaction of streamflow with adjacent alluvial groundwater has been well known in hydrology for decades (Cooper and Rorabaugh, 1963; Pinder and others, 1969). This interaction is heightened during floods and is further amplified when stream channels receive artificial floods such as those derived by release from an irrigation canal or discharged from a tunnel, aqueduct, or pipe (Hancock, 2002) as occurs in the Esopus Creek. Gaged annual runoff of the Shandaken Tunnel exceeded the difference between the annual runoff at the Coldbrook streamgage and the estimated natural mean annual runoff at Coldbrook, which is consistent with small net annualized losses caused by induced infiltration along the reach. But these differences were small on an annual basis, averaging 8.4 percent of the difference between Coldbrook streamgage flow and natural estimates during WYs 1932 through 2012 and 14.5 percent of the difference during WYs 1971 through 2012. Factors such as increased evaporative losses from artificially elevated levels of shallow 


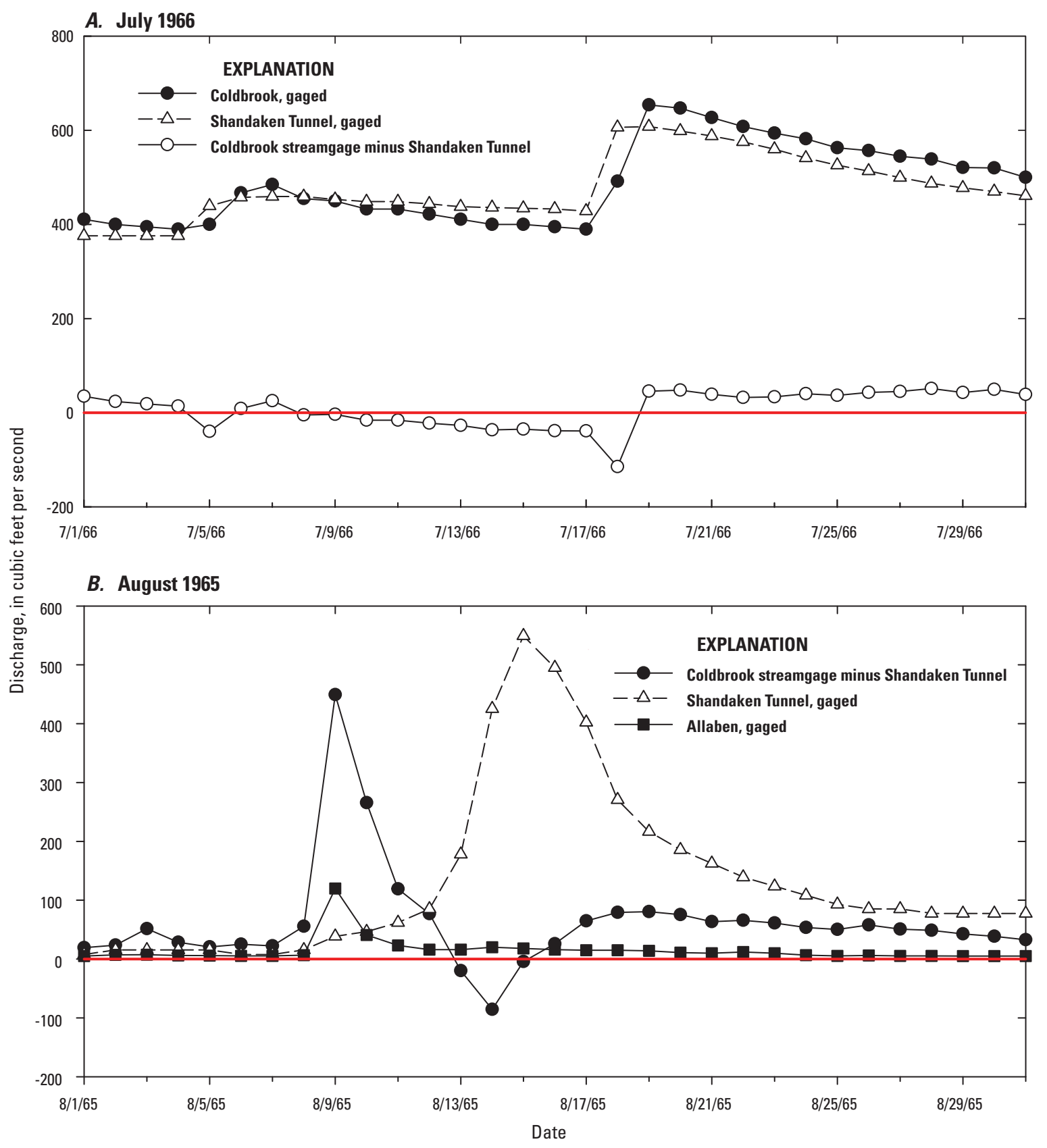

Figure 6. Discharge measures from streamgages on the Esopus Creek and the Shandaken Tunnel, New York. A. Coldbrook streamgage (01362500), Shandaken Tunnel, and Coldbrook streamgage minus Shandaken Tunnel discharge during July 1966, and B. Coldbrook streamgage minus Shandaken Tunnel, Shandaken Tunnel, and Allaben streamgage (01362200) discharge during August 1965. Red horizontal line on each plot indicates discharge of zero. 
groundwater may have played a role in the apparent long-term loss of tunnel discharge.

These imbalances in long-term runoff, when considered along with the day-by-day analysis presented in this section, might be interpreted to indicate that induced infiltration resulting from Shandaken Tunnel discharge causes long-term losses of stream water to groundwater. This interpretation, however, may be unwarranted because measured discharge values have uncertainty of about 10 percent, and the uncertainty of natural flow estimates is even greater. Consideration of uncertainty indicates that the combined runoff values cannot be viewed conclusively as exceeding those of natural runoff. For some days, comparisons of the Shandaken Tunnel and Coldbrook discharge records also show exfiltration of excess flow from adjacent alluvial groundwater into the Esopus Creek (the opposite effect of induced infiltration), which is consistent with the idea that induced infiltration results in only temporary losses of streamflow. Regardless of what causes Shandaken Tunnel discharge to exceed that measured at the Coldbrook streamgage on many days throughout the record, the existence of this phenomenon resulted in a change from the originally proposed study approach (subtracting the tunnel flow from Coldbrook discharge to yield a natural discharge record) to the use of a regression-based statistical approach with nearby streams as predictive variables.

\section{Summary}

This report summarizes the results of a study by the U.S. Geological Survey (USGS) in cooperation with the New York City Department of Environmental Protection to estimate natural discharge in the Esopus Creek at two USGS streamgages on the Esopus Creek at Coldbrook (10362500) and Mount Marion (01364500), New York. The Coldbrook streamgage is affected by out-of-basin discharge from the Shandaken Tunnel, and the Mount Marion streamgage is affected by impoundment in the Ashokan Reservoir and subsequent release through the Catskill Aqueduct. Natural daily discharge values for water years (WYs) 1932 to 2012 were estimated at the Coldbrook streamgage by multiple linear regression using nearby daily discharge values from streamgages that are not greatly affected by human activities. These natural discharge estimates for the Coldbrook streamgage were then added to those estimated by the New York Streamflow Estimation Tool for the basin area from Coldbrook downstream to the Mount Marion to estimate natural daily discharge at the Mount Marion streamgage for WYs 1932 through 2012. These estimated natural daily discharge values were compared with those of the measured daily discharge at the two streamgages for consecutive-day low- and high-flow metrics and for the full range of flow exceedance values. Annual runoff values derived from these natural estimates and gaged discharge values were compared with each other and with those derived from nearby streamgages with little impact from human activities.
Gaged discharge in the Esopus Creek at two USGS streamgage sites produced mean annual runoff values that fell outside the current range observed in unimpounded streams in the Catskill region of New York. However, natural discharge estimates produced runoff values well within this range that are consistent with natural runoff patterns in this region. Natural discharge estimates at the Coldbrook streamgage (01362500) were lower than gaged discharge values, which is consistent with the expected effects of inflow from the Shandaken Tunnel to the Esopus Creek. Gaged daily-discharge values varied from two to more than three times greater than natural discharge estimates in the low- to moderate-flow range (50- to 99-percent flow exceedance), but the relative difference between gaged and natural discharge declined sharply at the lowest 1 percent of daily-discharge values.

One plausible explanation for this lower relative difference is that tunnel inflow is most likely to induce infiltration into the adjacent alluvial aquifer at the lowest flow conditions. The presence of streamflow losses that were likely due to infiltration induced by Shandaken Tunnel discharge was identified in an analysis according to which daily tunnel discharge exceeded daily discharge at the Coldbrook streamgage on about 5 percent of the days during WYs 1932 through 2012. The infiltration losses are probably not of long duration, and exfiltration back to the stream is likely following a rapid increase in tunnel discharge. Long-term runoff patterns suggest the possibility of slight permanent losses of tunnel discharge, which could also be caused in part by increased evaporation from shallow groundwater. However, the sum of tunnel discharge and Coldbrook discharge exceeded the estimated natural discharge at the Coldbrook streamgage by only 8.4 percent during WYs 1932 through 2012 and by 14.5 percent during WYs 1971 through 2012 (values that are close to the 10-percent uncertainty of gaged discharge values at the Coldbrook streamgage). Additionally, with consideration of the uncertainty of these natural flow estimates, which is substantially greater than 10 percent of Coldbrook discharge, permanent losses over long periods of time caused by induced infiltration cannot be confirmed on the basis of this analysis.

Flow-exceedance values and annual consecutive-day high-flow metrics indicate that the relative difference between gaged daily discharge and estimated natural daily discharge at the Coldbrook streamgage narrows at the highest flows. For example, 1-day, 3-day, and 7-day maximum annual gaged discharge differed by less than 10 percent from natural discharge, within the 10-percent uncertainty range of gaged daily discharge values at this site. In contrast to previous reports of greatly increased flooding induced by Shandaken Tunnel discharges, these results indicate that the tunnel has only a minor effect on streamflow in the Esopus Creek during floods.

Impoundment of the Esopus Creek in the Ashokan Reservoir sharply diminishes discharge at the downstream Mount Marion streamgage (01364500) relative to natural flow estimates for this site. Estimated natural discharge is about three times greater than gaged discharge throughout the moderateto low-flow range (50- to 90-percent flow exceedance). These 
natural discharge values are lower than would be expected considering that the true watershed area (419 square miles $\left.\left[\mathrm{mi}^{2}\right]\right)$ is about 3.7 times greater than the effective watershed area $\left(112 \mathrm{mi}^{2}\right)$ when water is not being diverted from the reservoir. This diversion of flow into the Esopus Creek, which is reflected in the gaged discharge at the Mount Marion streamgage, may explain in part why the gaged discharge is greater than would be expected from the effective watershed area. The results described in this report indicate an effective watershed area of about $140 \mathrm{mi}^{2}$ at low to moderate flow conditions based on the Mount Marion streamgage record.

These relative differences between the Mount Marion gaged discharge and estimated natural discharge decrease at high flow, but gaged daily discharge is still 25 to 43 percent less than estimated natural daily discharge for all calculated annual high-flow metrics, and this mean relative difference is 27.7 percent for the 1 percent of highest flows from October 1, 1970, to September 30, 2012. These high-flow results are consistent with previous observations that the Ashokan Reservoir and other Catskill reservoirs operated by the New York City Department of Environmental Protection, though not designed as flood-control reservoirs, decrease downstream flood peaks. The analysis in this report indicates that the highest daily discharge values are diminished by a mean of 43 percent during WYs 1971 through 2012, whereas a previous analysis indicated a 60 percent diminishment of flood peaks. The previous analysis was based on 5 instantaneous flood peaks, whereas the current analysis is based on 43 daily peaks, which may account for this difference.

\section{References Cited}

Archfield, S.A., and Vogel, R.M., 2010, Map correlation method-Selection of a reference streamgage to estimate daily streamflow at ungaged catchments: Water Resources Research, v. 46, no. 10, W10513, p. 1-15. [Also available at http://dx.doi.org/10.1029/2009WR008481.

Archfield, S.A., Vogel, R.M., Steeves, P.A., Brandt, S.L., Weiskel, P.K., and Garabedian, S.P., 2010, The Massachusetts sustainable-yield estimator-A decision-support tool to assess water availability at ungaged stream locations in Massachusetts: U.S. Geological Survey Scientific Investigations Report 2009-5227, 41 p. plus CD-ROM. [Also available at http://pubs.usgs.gov/sir/2009/5227/.]

Cooper, H.H., Jr., and Rorabaugh, M.I., 1963, Ground-water movements and bank storage due to flood stages in surface streams: U.S. Geological Survey Water Supply Paper 1536-J, p. 343-366. [Also available at http://pubs.er.usgs. gov/publication/wsp1536J.]
Duan, Naihua, 1983, Smearing estimate-A non-parametric retransformation method: Journal of the American Statistical Association, v. 78, p. 605-610. [Also available at http:// dx.doi.org/10.1080/01621459.1983.10478017.]

Eng, Ken, Wolock, D.M., and Carlisle, D.M., 2013, River flow changes related to land and water management practices across the conterminous United States: Science of the Total Environment, v. 463-464, p. 414-422. [Also available at http://dx.doi.org/10.1016/j.scitotenv.2013.06.001.]

Foster, H.A., 1934, Duration curves: American Society of Civil Engineers Transactions, v. 99, p. 1213-1267.

Francis, A.M., 1988, Catskill rivers-Birthplace of American fly fishing: Guilford, Conn., Lyons Press, 272 p.

Galusha, Diane, 1999, Liquid assets-A history of New York City's water system: Fleischmanns, N.Y., Purple Mountain Press, $303 \mathrm{p}$.

Gazoorian, C.L., 2015, Estimation of unaltered daily mean streamflow at ungaged streams of New York, excluding Long Island, water years 1961-2010: U.S. Geological Survey Scientific-Investigations Report 2014-5220, 29 p. [Also available at http://dx.doi.org/10.3133/sir20145220.]

Gleick, P.H., 1996, Basic water requirements for human activities-Meeting basic needs: Water International, v. 21, no. 2, p. 83-92. [Also available at http://dx.doi. org/10.1080/02508069608686494.]

Hancock, P.J., 2002, Human impacts on the stream-groundwater exchange zone: Environmental Management, v. 29, no. 6, p. 763-781. [Also available at http://dx.doi.org/ 10.1007/ s00267-001-0064-5.]

Iwan, G.R., 1987, Drinking water quality concerns of New York City, past and present: Annals of the New York Academy of Sciences, v. 502, p. 183-204. [Also available at http://dx.doi.org/10.1111/j.1749-6632.1987.tb37652.x.]

Kane, Melinda, and Erickson, J.D., 2007, Urban metabolism and payment for ecosystem services-History and policy analysis of the New York City water supply: Advances in the Economics of Environmental Resources, v. 7, p. 307-328. [Also available at http://dx.doi.org/ 10.1016/ S1569-3740(07)07013-7.]

Magilligan, F.J., and Nislow, K.H., 2005, Changes in hydrologic regime by dams: Geomorphology, v. 71, no. 1-2, p. 61-78. [Also available at http://dx.doi.org/10.1016/j. geomorph.2004.08.017.]

McClure, Chris, 2007, Clarifying the definition of point source pollution and unitary water theory - Catskill Mountains Chapter of Trout Unlimited, Inc. v. City of New York: Great Plains Natural Resources Journal, v. 12, p. 69-85. 
Milone and MacBroom, Inc., 2009, River reconnaissance report for sustainable river management-Lower Esopus Creek, Ulster County, New York: Cheshire, Conn., Milone and MacBroom, Inc. Report MMI\#3618-01-1, 46 p.

New York State Department of Environmental Conservation, 2014a, Chapter X-Division of Water: New York State Department of Environmental Conservation regulations, accessed February 13, 2014, at http://www.dec.ny.gov/ regs/2485.html.

New York State Department of Environmental Conservation, 2014b, Part 670 - Reservoir releases regulations-Schoharie reservoir Shandaken tunnel-Esopus Creek: New York State Department of Environmental Conservation regulations, accessed June 23, 2014, at http://www.dec.ny.gov/ regs/4609.html.

Northeast Regional Climate Center, 2014, 1971-2000 mean, Slide Mountain, 2,680-foot elevation: Northeast Regional Climate Center Climate Information for Management and Operational Decisions system, accessed February 19, 2014, at http://climod.nrcc.cornell.edu.

Pinder, G.F., Bredehoft, J.D., and Cooper, H.H., Jr., 1969, Determination of aquifer diffusivity from aquifer response to fluctuations in river stage: Water Resources Research, v. 5, no. 4, p. 850-855. [Also available at http://dx.doi. org/10.1029/WR005i004p00850.]

Postel, S.L., and Thompson, B.H., Jr., 2005, Watershed protection-Capturing the benefits of nature's water supply services: Natural Resources Forum, v. 29, no. 2, p. 98-108. [Also available at http://dx.doi.org/10.1111/j.14778947.2005.00119.x.]

Postel S.L., Daily, G.C., and Ehrlich, P.R., 1996, Human appropriation of renewable fresh water, Science, v. 271, no. 5250, p. 785-788. [Also available at http://dx.doi.org/ 10.112/science.271.5250.785.]

Randall, A.D., 1996, Mean annual runoff, precipitation, and evapotranspiration in the glaciated northeastern United States, 1951-80: U.S. Geological Survey Open-File Report 96-395, 2 pls. [Also available at http://ny.water.usgs.gov/ pubs/of/of96395/OF96-395.html.]

Rantz, S.E., and others, 1982a, Measurement and computation of streamflow-Volume 1. Measurement of stage and discharge: U.S. Geological Survey Water Supply Paper 2175, p. 1-284. [Also available at http://pubs.usgs.gov/wsp/ wsp2175/.]

Rantz, S.E., and others, 1982b, Measurement and computation of streamflow-Volume 2. Computation of discharge: U.S. Geological Survey Water Supply Paper 2175, p. 285-631. [Also available at http://pubs.usgs.gov/wsp/wsp2175/.]
Rich, J.L., 1935, Glacial geology of the Catskills: New York State Museum Bulletin, no. 299, 180 p.

Richter, B.D., Baumgartner, J.V., Powell, Jennifer, and Braun, D.P., 1996, A method for assessing hydrologic alteration within ecosystems: Conservation Biology, v. 10, no. 4, p. 1163-1174. [Also available at http://dx.doi.org/10.1046/ j.1523-1739.1996.10041163.x.]

Rosenberg, D.M., McCully, Patrick, and Pringle, C.M., 2000, Global scale environmental effects of hydrological alterations: Introduction: BioScience, v. 50, p. 746-751. [Also available at http://dx.doi.org/10.1641/00063568(2000)050[0746:GSEEOH]2.0.CO;2.]

Smith, L.E.D., and Porter, K.S., 2010, Management of catchments for the protection of water resources-Drawing on the New York City watershed experience: Regional Environmental Change, v. 10, no. 4, p. 311-326. [Also available at http://dx.doi.org/10.1007/s10113-009-0102-z.]

Soll, David, 2013, Empire of water-An environmental and political history of the New York City water supply: Ithaca, N.Y., Cornell University Press, 283 p.

Suro, T.P., and Firda, G.D., 2006, Flood of April 2-3, 2005, Neversink River basin, New York: U.S. Geological Survey Open-File Report 2006-1319, 106 p. [Also available at http://pubs.usgs.gov/of/2006/1319/.]

Suro, T.P., and Firda, G.D., 2007, Flood of April 2-3, 2005, Esopus Creek basin, New York: U.S. Geological Survey Open-File Report 2007-1036, 85 p. [Also available at http:// pubs.usgs.gov/of/2007/1036/.]

Swaney, D.P., Limburg, K.E., and Stainbrook, Karen, 2006, Some historical changes in the patterns of populations and land use in the Hudson River watershed: American Fisheries Society Symposium, v. 51, p. 75-112.

Theil, Henri, 1961, Economic forecasts and policy (2d ed), v. 15 of Contributions to Economic analysis: Amsterdam, North-Holland Publishing Co., 567 p.

U.S. Environmental Protection Agency, 2014, New York City watershed: U.S. Environmental Protection Agency Web page, accessed February 19, 2014, at http://www.epa.gov/ region $02 /$ water/nycshed/.

U.S. Geological Survey, 2014a, The StreamStats program: U.S. Geological Survey StreamStats database, accessed February 18, 2014, at http://water.usgs.gov.osw/streamstats. index.html. [Available November 19, 2014, at http://water. usgs.gov/osw/streamstats/index.html.]

U.S. Geological Survey, 2014b, United States Geological Survey (USGS) - Water resources of New York: U.S. Geological Survey Web page, accessed February 19, 2014, at http:// ny.water.usgs.gov/. 
U.S. Geological Survey, 2014c, USGS 01364500 Esopus Creek at Mount Marion NY: U.S. Geological Survey National Water Information System, accessed June 14, 2014, at http://waterdata.usgs.gov/ny/nwis/uv/?site no $=01364500 \&$ PARAmeter_cd $=00065,00060$.

Van Burkalow, Anastasia, 1959, The geography of New York City's water supply - A study of interactions: Geographical Review, v. 49, no. 3, p. 369-386.

Vörösmarty, C.J., and Sahagian, Dork, 2000, Anthropogenic disturbance of the terrestrial water cycle: BioScience, v. 50, p. 753-765.

Wada, Y., van Beek, L.P.H., and Bierkans, M.F.P., 2013, Modelling global water stress of the recent past - On the relative importance of trends in water demand and climate variability: Hydrology and Earth System Sciences, v. 15, p. 3785-3808. [Also available at http://dx.doi.org/10.5194/ hess-15-3785-2011.]

Wolf, A.T., Kramer, Annika, Carius, Alexander, and Dabelko, G.D., 2005, Managing water conflict and cooperation, chap. 5 of State of the world 2005-Redefining global security: New York, The Worldwatch Institute, p. 80-95. [Also available at http://transboundarywater.geo.orst.edu/publications/ abst_docs/wolf_sow_2005.pdf.]

Zembrzuski, T.J., Jr., and Evans, M.L., 1989, Flood of April 4-5, 1987, in southeastern New York state, with flood profiles of Schoharie Creek: U.S. Geological Survey WaterResources Investigations Report 89-4084, 41 p. [Also available at http://pubs.er.usgs.gov/publication/wri894084.] 
For additional information write to: Director, New York Water Science Center U.S. Geological Survey

425 Jordan Road

Troy, NY 12180-8349

dc_ny@usgs.gov

Information requests:

(518) 285-5602

or visit our Web site at: http://ny.water.usgs.gov

Publishing support by:

The Pembroke Publishing Service Center. 
